and interesting than it would otherwise have been. $\mathrm{He}$ re-visited India and Burma in connexion with this work and was engaged on the preparation of a further volume to bring the history up to 1940 at the time of his death-I recently took over from him the task of completing and publishing it (extending it to the end of the British regime in 1947).

As a teacher, Stebbing had very definite ideas of what was best for his students, and kept as firm a rein on the curriculum as he did on his horse. He always rejected any suggestion of loading up his undergraduate course with more basic science, considering that practical forestry had not yet advanced enough for it to be of any value : his course was accordingly more weighted on the technological side than elsewhere-which might not have been expected in view of his own early specialization. Possibly he was inclined to overstress the model of advanced European practice, rather curiously adding an over. dose of engineering and surveying appropriate to India and Burma in the old days.

No account of Stebbing's life would be complete without reference to his personality. Small and spare, he was exceptionally 'tough' both on foot and as a horseman, and remained so until an unusually advanced age. Stories of his walking performances still persist in India, while his equestrian ride from his home in Kent (Romden Castle) to London in 1935 when he was sixty-five was no isolated feat.

During much of his time at Edinburgh, Stebbing had the largest number of students among the four university schools of forestry in the United Kingdom. Many of them had been sent from overseas, and these and many others are serving or have served in the forest services of Britain and all countries of the Commonwealth; in fact, cases could be quoted where the large majority of the officers of the Forest Department were his men. One can safely prophesy that his record will never be repented, and he will long be remembered in all forestry circles.

H. G. Champion

\section{Prof. E. J. Kraus}

Dr. EzRA J JCOB KraUs died at Corvallis, Oregon, on February 28 at the age of seventy-four. He was distinguished throughout the United States both for his massive contribution to seientific horticulture and for his flair for friendship with young botanists. He graduated from Michigan State University in 1907 and spent the first eleven years of his academic career in Oregon State College. In 1919 he went from Oregon to the University of Wisconsin; after a few years there he accepted an invitation to a chair in the botany department in the University of Chicago, where he stayed until his retirement in 1949.

The scientific work for which Kraus is remembered is his analysis of the balance of carbohydrate and nitrogen in plants in relation to fruiting. He demonstrated that many crop plants did not bear fruit unless a balance was maintained between these two classes of compounds. Some of his disciples greatly over-simplified his ideas by talking loosely about a carbohydrate-nitrogen ratio (or even a $\mathrm{C} / \mathrm{N}$ ratio) ; but Kraus himself always realized that the relation between chemical composition and fruiting was a subtle and complex one, and he was impatient of these facile simplifications. Kraus's ability to diagnose why crops failed to bear fruit was quite astonishing. He showed (for example) how low yields in the apple orchards in the Hood River valley were due to over-manuring coupled with early pruning. A score of other examples could be cited, where fruit growers were able to improve their yields by controlling the balance of carbohydrate and nitro. gen by means of simple horticultural practices : manuring, pruning, ringing and the like.

In Chicago he turned his attention to the anatomical effects of plant growth hormones, and (during the War, when he was attached to the U.S. Department of Agriculture) to the use of hormone-like chemicals for weed control ; in both these fields he did important work.

But in the memories of hundreds of students Kraus will survive as a man rather than as a research worker. His influence on the graduate students who passed through his hands was enormous. It was conveyed through a quiet approach, a slightly cynical modesty. a bubbling sense of humour, and above all an impres. sion that the priority which Kraus put first in his life was to spend time with young men, to talk to them, to travel with them, to pass on to them his enthusiasm for scientific horticulture. He was a capital 'debunker' : indeed his interest in applied science and his suspicion of pure science sometimes led him to distrust research which seemed too sophisticated, and the succession of young men who had the privilege of his friendship remember with zest his mocking pragmatism.

Kraus disliked administration and committees, and he retired early (partly on account of illness) to spend the rest of his life doing the work he loved in the place he loved. From 1949 until his death, as a visiting professor of horticulture at Oregon State College, he devoted his time to horticulture, especially to the production of new varieties of chrysanthemums, and to cultivating his friends. He died after a long and painful succession of illnesses.

Kraus received wide recognition for his distinction in American botany. $\mathrm{He}$ was president of the Botanical Society of America in 1933 and of the American Society of Plant Physiologists in 1928, and he won many medals and prizes for his horticultural work. Much of his work is inevitably out of date: but his influence on a generation of botanists will endure.

E. AshbY

\section{Sir Leonard Woolley}

Charles Leonard Woolley. who died on February 20 , nearly eighty years old, was perhaps the ruary 20, nearly elly famous archæologist of his most internation reputation was built upon far more generation. fact that he best represented the ordinary man's notion of an archrologist, namely, a digger-up of the lore, but especially the treasures, of antiquity. of the lore, but esperis his life's work, and certainly his successes in it were outstanding. He was constantly in the field (in Egypt, Syria, above all in Iraq), he in the field (in Egypt, institution, he never undertook to teach students (except by practical example to his assistants), and he scarcely attempted academic literature in his subject.

Yet even among those few who could have worked so widely and so hard as he, many would have fallen short for want of certain talents which Woolley pirst, by some scarcely explicable gift, possessed. find the most rewarding spot to work. he could find the choice of Atshanah (the ancient 